\title{
Enhancing Mentally Retarded Students' Comprehension: The Development of MASH Project-Based Reading Material
}

\author{
Lulu Asyrifah, Yudhi Arifani \& Rohmy Husniah \\ Universitas Muhammadiyah Gresik \\ (yudhi_arif@umg.ac.id)
}

\begin{abstract}
The development of reading material through Project Based Learning (PBL) strategy using MASH is aimed to meet mentally retarded students' learning and target needs in EFL English reading courses. This study employed a research and development design which comprises seven stages, namely: a) students' need analysis, design of MASH Project based reading, development, expert validation, implementation, reading material evaluation, and final product in the form of MASH project based reading material. The result of the reading material development took resulted six chapters in terms of number 11-20, expression agree/disagree, and part of house where containing material of the topic, video, and exercises that utilize Project-Based Learning strategy. The result of experts' validation from an English teacher who assessed the material revealed the score was 78\% that sorted out into 'very good' category and an Informatics teacher who assessed the media revealed the score was $74 \%$ that sorted out into 'good' category. While, the result of the students' response related to the product showed the total score was $79 \%$ that the students agree with MASH media to be used in learning process. As its effectiveness toward the improvement of mentally retarded students' reading comprehension is not measured yet, so an experimental study is addressed for further research to meet the issue of MASH reading material effectiveness and conduct the similar project with another media to develop more reading materials and activities.
\end{abstract}

Keywords: reading, MASH, PBL strategy, mentally retarded students

Reading is an essential skill to be learned by all levels of students, included mentally retarded students. Every student can improve their knowledge transfer by extracting information, increase vocabularies, grammatical pattern, and good method of understanding for personal growth and development through reading (Grellet, 1999; Dadzie, 2008; Mart, 2012; Maina, et,al, 2014; Owusu-Acheaw, M. \& Larson, A.G, 2014). Among the above advantageous of reading, a debate in terms of difficulties teaching reading for mentally retarded students is highlighted.
Preliminary research is conducted by the researcher that it is found some problems which it is not found out the text ofmaterial provided in the textbook, less of media and activities, even less motivation in learning English, especially reading.

In addressing the above issue, awareness should be taken to answer it in which giving special consideration to adapt for mentally retarded students (Mpofu \& Chimhenga, 2013). They can learn basic reading skill if they are given the appropriate strategy. This study utilizes Project-Based 
Learning (PBL) srategy which is a learning teaching method utilizing a project to be worked collaboratively by the students to improve skill and knowledge through research assignment, authentic question, and welldesigned product (Sumarni, 2015; Kizkapan \& Bektas, 2017).

Further, Guven and Duman (2007), PBL shows its effectiveness to build mentally retarded students' ability in social and literacy skill while utilizing computer than printed material will increase the learners' attention span (Wah, 2007). In this case, MASH (Macromedia Flash) is offered to complete the teaching-learning performances containing pictures, sound, text, video, and animation (Saputra \& Tianina, 2013; Lisda, et.al, 2015). Hence, the aim of this study is to develop reading material through PBL strategy using MASH for mentally retarded students.

\section{Reading for Mentally Retarded Students}

One of crucial English skills to be mastered by the students is reading.Every student can improve their knowledge transfer by extracting information, increase vocabularies, grammatical pattern, and good method of understanding for personal growth and development through reading (Grellet, 1999; Dadzie, 2008; Mart, 2012; Maina, et,al, 2014; Owusu-Acheaw, M. \& Larson, A.G, 2014). The reader should know their goal of reading before they get the comprehension of the text itself, even it also look for simple, skim, learn, write, critique the information for general comprehension (Smith, 2004; Grabe \& Stoller, 2002).Further, reading is also taught for disability students included mentally retarded students who have disable in intellectual functioning and in adaptive behavior, social communication, difficult in stuttering and pronouncing certain words, lack of attention and short-term memory (Vig \& Jedrysek, 2004; Drossinou, et.al, 2009; Thurlow, et.al, 2009; Allor, et.al, 2010; Alqahtani, 2013, Hosseinkhanzadeh, 2014).

Teaching English for mentally retarded students does not require to be taught deeply but it emphasizes more on daily or in application for daily communication. The reading length is also paid attention to develop material for mentally retarded students which the average sentence length of 100 words containing only three or four sentences accompanied by literal and inferential questions (Walton, 1960; Fajardo, 2014). Some activities can be adapted are placing the pictures correctly, answering the questions by choosing the correct words, and placing the words in the correct order (Lundberg \& Reichenberg, 2013).

\section{Project-Based Learning}

The students will learn more when they are responsible for their own learning. Project-based learning emphasizes educational opportunities which involves a studentcentered model to study around project that integrates language skill (Hedge, 1993; Yusoff, 2006; Du \& Han, 2016). There are six steps of PBL strategy according to Sumarni (2015), those are essential questions, plan for a project, create a schedule, monitor and assess the students doing the project, and evaluate the experience.

\section{Macromedia Flash}

In this case, MASH (Macromedia Flash) is offered to complete the teaching-learning performances. Macromedia flash is a package used to design, presentation and publication. The program is the supporting usage in picture, sound, text, video, and animation (Saputra \& Tiarina, 2013).According to Lisda, et.al (2015), Macromedia flash learning method is learning system using software-hardware which facilitates the data process in the form of picture, video, photography, graphic, and animation, in collaboration with sound, text, and voice data interactively controlled by computer. It is also providing a sort of quiz which will contribute for teaching-learning process more interesting than before. Explaining and delivering lesson through picture, video, in collaboration with text attractively will make hearing-impaired 
learners are more interested in learning and comprehending the material of reading.

\section{Method}

Design of the Study

The research design of this study utilizes a Research and Development model initiated by McGriff (2000) which is ADDIE model with some changes. It covers analysing mentally retarded students' need, designing prototype, developing reading text and activities, assessing from expert validation related to the product, implementing the product, evaluating the product, and final product. The implementation is conducted within seven meetings to 9 of junior highmentally retarded students at SLB Negeri Cerme.

\section{Analysing Phase}

This phase is to define the problem, identify the problem source and determine possible solutions (McGriff, 2000). The researcher conducts an interview with the English teacher of SLB Negeri Cerme and administers a questionnaire to 9 mentally retarded students in order to generate their learning needs and target needs on the reading goal and activities.

\section{Designing Phase}

In this phase, instructional designers begin to create a framework and create the project in order to meet the goals which is identified in analyse phase (McGriff, 2000). The result of questionnaire is to formulate a course grid in the design chapter that becomes a guide in developing the material.

\section{Developing Phase}

In this stage, the development of material and exercises are carefully accomplished by adapting the difficulty level of the text into three till four sentences or 100 words. The reading activities are classified into answering the literal questions (multiple choice), drag \& drop, and a project.

\section{Validating Phase}

This step is aimed to measure up the appropriateness of the product professionally by involving two experts, an English teacher who assessed the material and an Informatic teacher who assessed the media.

\section{Implementing Phase}

This phase is to transform the plan into action. This study conducted for seven meetings, included three chapters in terms of number 11-20, expression agree/disagree, and part of house.

\section{Evaluating Phase}

The next process in ADDIE model is Evaluation phase. It is very important to evaluate each step in order to make sure that we achieve our purposes using the instructional design and materials to meet the learner needs.

\section{Final Product}

The After completing the revision, the final product is in the form of developing reading material application for mentally retarded students.

\section{Results and Discussion}

Needs Analysis

The researcher gave six questions to English teacher of mentally retarded of SLB Negeri Cerme in order to get information about students' learning needs. The researcher describes the result of interview with English teacher as follows:

The first question was about curriculum which was applied in English learning process. The teacher answered that they used KTSP curriculum. In question number two, the researcher asked about the textbook which was used by English teacher, she said that the textbook is from the government that the content is for mentally retarded students, even though, there is no enough material for reading. It contains vocabularies and short dialogue.

The researcher also asked related to media, the teacher mostly used printed out material from the internet source for teaching and learning 
process, pictures, and also white board. For the fourth question, the researcher asked about the motivation and difficulties to teach English for mentally retarded students. She said that it is difficult to teach English for them, even their motivation is low. It had some factors that teaching English for them was only an introduction. She only taught vocabularies to the students, she ever tried to give a simple text to teach reading but they got difficult to read it. The lack of media also influenced unsuccessful teaching reading. She hoped to have interesting media for them besides using pictures to teach another skill of English to the mentally retarded students. In another hand, teaching other skills of English will give easiness to the students in doing examination.

The next question was about the appropriate tasks for the material. The students were given activities such as gluing the picture with the words or rewriting some words that the teacher gave. In developing tasks, the teacher suggested to provide more interesting and easy tasks for them to gain their motivation. The last question was related to the strategy that teacher used, she answered that the teaching process uses conventional method, the teacher explained the material, drilled, and gave activities. Those activities repeated to the next meeting.

Meanwhile, the result of need analysis from the questionnaire showed that the purpose of the students' learning reading, $44 \%$ of the students stated to understand the text, $33 \%$ of the students answered to increase vocabulary, and $22 \%$ response to be able to answer all of the questionsin the exam correctly. As many as $67 \%$ of the students stated that they have difficulties of vocabulary, $33 \%$ stated on lack of supporting media, and $11 \%$ meant a number of tasks to do. Again, the students choose story (picture+text) amounted 56\% response, $22 \%$ stated on paragraph and dialogue, $56 \%$ answered text with pictures, and $22 \%$ of the students want text consisted of sentences and vocabulary list. Further, they want media which are picture+text and computer as many as $44 \%$, and also video as many as $11 \%$. The students choose activities which are matching task (56\%), exercising with multiple choice (33\%), and arranging random sentences (11\%) by doing them in a group (56\%), individual and in a pair (22\%).

Design

The result of syllabus development of reading material emphasizing on three daily topic is designed for one semester teaching program. It is formulated the objective of each topic that be able to empower the comprehension of number 11-20, expression agree/disagree, and part of house with 160180 mins as the time allotment. Further, the assessment of reading is identified into individual, pair, and group assessment.

\section{Development}

Developing material and exercises are created on MASH that begun with drawing of the background, the entire menu of pages, material, and some tasks in terms of pair activity (multiple choice questions), individual activity (drag\&drop), and group activity which is the implementation of PBL strategy.

\section{Expert Validation}

The result of the material assessment in MASH from an English teacher of mentally retarded is $78 \%$ labelled into 'very good' category while the assessment of media from an Informatic teacher of mentally retarded students is $74 \%$ labelled into 'good category'.

\section{Implementation}

This study conducts seven meetings to nine of mentally retarded students which they do matching task and answering literal questions of a story that provided in MASH related to the three topics. The difference activity can be seen when doing the project for each topic. the studentsshould read a simple paragraph about missing object in the classroom related to the first topic and then find out one of missing thing (book, pen, pencil, and eraser) as many as number 11-20 where the researcher had already set them in the library. The result shows positive response from mentally retarded students that they 
are success in doing the project on time. One of group is success to collect 12 books and another group is success to collect 11 pens.

Further, the second topic about expression agree/disagreeis tried out to the students by choosing one theme (birthday present, exercise, eating) then arrange them in correct order with their team, unfortunately, this project is failed to do. The students get obstacle to comprehend the sentences and they feel angry, bored, and do not want to continue the project. The researcher revises the project of chapter 2 by adding mini dictionary of difficult terms and changing the method giving instruction. The project of chapter 2 is continued to the fifth meeting by asking the students to choose one of themes by clicking on the MASH. The researcher instructs them to arrange the random sentences into a good dialogue by finding out the sentences in some places. The random sentences were able to be found in the English teacher's room for theme of birthday present, the theme of exercise is in the computer room, and the theme of eating is in the canteen. One of group directly goes to the canteen and asks the seller to give the sentences. The researcher asks them to go back to the classroom and instructs them to arrange it by seeing the meaning of difficult words in MASH. Another group is confused to choose the theme, the researcher asks question "Do you like a present or running?", they answer "present". Then, the researcher asks them to go to the English teacher's room and asks the teacher to give the sentences.

Those two groups are success in arranging the random sentences in a group by the time that the researcher set. The improvement is appeared that the students be able to arrange them by finding out the sentences and reading mini dictionary. The last project of the chapter 3 is that the students should read a simple paragraph about a dream house, then compose a paragraph related to their own dream house and cut the picture of favourite room provided. They could write down based on the clues, such as "how many rooms do they have and their favourite room". The project also gives positive response that mentally retarded students be able to do the project as well.

\section{Evaluation and Revision}

The revisions are gotten from the experts in terms of adding mini dictionary and audios in order to the students comprehend the material and pronounce the vocabularies correctly while the navigation button and font of chapters should be revised.

\section{Final Product}

The distribution of the students' response questionnaire is to determine the students' perception toward reading material through PBL strategy using MASH and it shows $79 \%$ that means the students agree on the product.

The development of reading material through PBL strategy using MASH directed for mentally retarded students of SLB Negeri Cerme that perform very good category as it is shown in the average score of validation of $78 \%$ for the material and $74 \%$ identified the media in good category within the scale of Strongly Agree to Strongly Disagree. The detailed results from the students' response show the average score of $79 \%$ that reveal the students agree with MASH media to be used in learning process. These data described that the development reading material have already met the students' need analysis.

The try out is undertaken for seven meetings to implement three topics in terms of number 11-20, expression agree/disagree, and part of house. Even though, the project implementation of the second topic which is about expression agree/disagree in the fourth meeting does not match the criteria of success but significant improvement occurred in the fifth meeting. It happens where in the fourth meeting most of the students in each group do not understand the words from the sentences provided.

On the basis of the above phenomena, the researcher creates some attempts to simplify 
the sentences and changes the way giving instruction to the students. The researcher adds a mini dictionary in order to mentally retarded students be able to comprehend the meaning of random sentences. It was supported by Allor, et.al (2010), mentally retarded students could read by connecting the text to the meaning. Moreover, the researcher also changes the way giving instruction doing the project to find out the random sentences in some places and arrange them into a good dialogue with their team.

In fact, in the fifth meeting, it can improve students' ability in doing the project by understanding the content of the sentences better than before. Hence, an awareness of students' problem becomes a crucial factor for the teacher in which Cramer and PrenticeDunn (2007) and Cobb et al. (2006) also stated that an effective teacher has a role to comprehend the students' obstacles. Further, the rest of the implementation are also success and be able to engage mentally retarded students' interest in learning reading through PBL strategy using MASH media. PBL strategy is effective to be implemented for the students because it would be able to increase their social communication while MASH (Macromedia Flash) supports mentally retarded students' senses and have a longer attention. It is in line with Wah (2007) revealed that mentally retarded students have a longer attention span when interacting with the computer than printed material.

This finding supports the previous studies which are conducted by Diwangkara, et.al (2016). They developed 3D animation media for reading and writing through Adobe Flash for mentally retarded students. The result revealed that it was very positive to be applied for the students. Sundari, et.al (2015) also showed that mentally retarded students gave positive response for their study which was developing android application "Gredio" for learning reading. The application supported the students' learning process. Besides, Guven and Duman (2007) examined the effectiveness of Project-Based Learning for mentally retarded students. The result showed that PBL strategy was effective to be applied for elementary-mentally retarded students. In line with Nurcahyoko (2011) who conducted a study in developing reading material using Flash for elementary students. The result showed positive response that the students be able to comprehend the material.

\section{Conclusions}

This study concerned on the development reading material through PBL strategy using MASH by emphasizing on daily topics for 9 of junior high-mentally retarded students at SLB Negeri Cerme. The researcher found good result of the material assessment from an English teacher and media assessment from an Informatics teacher, also get positive response toward the product from mentally retarded students. Overall, this reading material through PBL strategy using MASH meets the students' need to learn reading more interesting and answer the gap that there is more reading material provided in the textbook. Furthermore, the researcher demonstrated that the involvement of larger samples might not be captured. Additional study to refine this development assess reading comprehension, fluency, speed and other skills. Moreover, as the results of need analysis administered in this study just involving smaller subjects so the involvement of larger samples from different schools and more additional chapters have to be examined. Finally, to address the issue of the effectiveness of the reading material through PBL strategy using MASH, an experimental study have to be designed for further study.

\section{References}

Allor, J., Mathes, P. G., Roberts, J. K., Jones, F. G., \& Champlin, T. M. (2010). Teaching Students with Moderate Intellectual Disabilities to Read: An Experimental Examination of A comprehensive 
Reading Intervention. Education and Training in Autism and Developmental Disabilities Journal, 45(1), 3-22.

Alqahtani, H. H. (2013). Computer usages to developing some of Language skills to students with Intellectual Disabilities. International Journal of Information Technology \& Computer Science, 7(1), 1-11.

Cobb, M., Fox, D., Many, J., Mattews, M., McGrail, E., \& Tinker, S. G. (2006). Mentoring in literacy education: A commentary from graduate students, untenured professors, and tenured professors. Mentoring and tutoring: Partnership in Learning, 14(4), 371-387. http://dx.doi. org/10.1080/1361126060073918

Cramer, R., \& Prentice-Dunn, S. (2007). Caring for the whole person: Guidelines for advancing undergraduate mentorship. College Students Journal, 41(4), 771-778

Dadzie, P. S. (2008) Reading for Education: The Roles of Libraries. Ghana Library Journal, 20(1), 1-14

Diwangkara, I K. S, Putrama, I. M., Sunarya, I. M. G. (2016). Developing 3D Interactive Learning Media for Reading Writing Drawing to Mentally Retarded Students. KARMAPATI, 5 (1), 1-10

Drossinou, et.al. (2009). Book for Teachers of Special Education. Activities for Learning Readiness. Spoken Word Psychomotor Activity, Mental Abilities, Emotional Organization. Athens: Ministry of Education-Pedagogical Institute, Textbook Publishing Organization

Du, X. M., \& Han, J. (2016). A Literature Review on the Definition and Process of Project-Based Learning and Other Relative Studies. Creative Education, 7, 1079-1083. http://dx.doi.org/10.4236/ ce.2016.77112
Fajardo, I. (2014). Easy-to-read textx for students with intellectual disability: Linguistic Factors Affecting Comprehension. Journal of Applied Research in Intellectual Disabilities

Grabe, W\& Fredricka L. S. (2011). Teaching and Researching Reading. London: Pearson Education Longman

Grellet, F. (1999). Developing Reading Skill. Cambridge University Press, pp 3-25

Guven, Y\& Duman, H. G. (2007). Project Based Learning For Children With Mild Mental Disabilities. International Journal of Special Education, 22 (1), 77-82

Hedge, T. (1993). Key Concepts in ELT: Fluency and Project. ELT Journal, 3, 275-277. http://dx.doi.org/10.1093/elt/47.3.275

Hosseinkhanzadeh, A. A. (2014). Identification of Social Skills Deficits in Students with Mental Retardation. International Journal of Psychology and Behavioral Research. 3(5), 402-411

Kizkapan, O. \& Bektas, O. (2017). The Effect of Project Based Learning on Seventh Grade Students' Academic Achievement. International Journal of Instruction, 10(1), 37-54

Lisda, W., Rahman, M. A., Atmowardoyo, H. (2015). The Use of Macromedia Flash Animation to Enhance Students English Writing Skill at the Seventh Grade of SMP Yapis 1 Fakfak-West Papua. ELT Worldwide, 2 (2), 45-62

Lunberg, I. and Reichenberg, M. (2013). Developing Reading Comprehension Among Students with Mild Intellectual Disabilities: An Intervention Study. Scandanavian Journl of Education Research, 57 (1) 89-100

Maina, E. N., Kochung, E. J., Oketch, O. (2014). Learning Strategies Used by Deaf Students in English Reading Comprehension in Secondary Schools 
for the Deaf in Kenya: Implications on Academic Achievement.International Research Journals, 5 (4), 122-130

Mart, C. T. (2012). Developing Speaking Skills through Reading. International Journal of English Linguistics, 2(6), 91-96

McGriff, S. J. (2000). Instructional System Design. College of Education, Penn State University

Mpofu, J\&Chimhenga,S. (2013). Challenges faced by Hearing Impaired pupils in learning: A case study of King George VI Memorial School. IOSR Journal of Research \& Method in Education, 2 (1), 69-74

Nurcahyoko, K. (2011). Developing Reading Material of Public ToleranceThrough Interactive Multimedia Using Flash Playerfor the Fourth Grade Students of Elementary School. Semarang State University

Owusu-Acheaw, M.\& Larson, A. G. (2014). Reading Habits Among Students and its Effect on Academic Performance: A Study of Students of Koforidua Polytechnic. Library Philosophy and Practice (e-journal). 1130 http://digital commons.unl.edu/libphilprac/1130

Saputra, H. J. G.\&Tiarina,Y. (2013). Using Macromedia Flash 8 To Help English Teacher To Build Media Toward Teaching Reading. Journal of English Language Teaching, 1 (2), 393-398

Smith, F. (2004). Understanding Reading: A Psycholinguistic Analysis of Reading and Learning to Read. London: Lawrence Erlbaum Associates

Sumarni, W. (2015). The Strengths and Weaknesses of the Implementation of Project Based Learning: A Review. International Journal of Science and Research, 4 (3),1-7

Sundari, K., Yudhi, B., Mutaqin, M. R. (2015).
Gredio Application Learned to Read Using the Phonetic Method for Mentally Disabled Children. Telkom University

Thurlow, M. L, et.al. (2009). Disabilities and Reading: Understandingthe Effects of Disabilities and TheirRelationship to Reading Instruction andAssessment. Minneapolis, MN: University of Minnesota, Partnership for Accessible Reading Assessment

Vig, S.\&Jedrysek,E. (2004). Mental Retardation in Young Children. EITI Newsletter: Univeristy Center for Excellence

Wah, L. L. (2007). Development of Multimedia Learning Reseources for Children with Learning Disabilities in An Undergraduate Special Education Technology Course. MEDC, 1, 29-36

Walton, M. B. (1960). A Reading Program for Primary Educable Mentally Retarded Children of Bailey COBB Elementary School. Nashvilie, Teunessee

Yusoff, D. H. (2006). Project-Based Learning Handbook "Educating the Millennial Learner". Malaysia 


\section{Appendix}
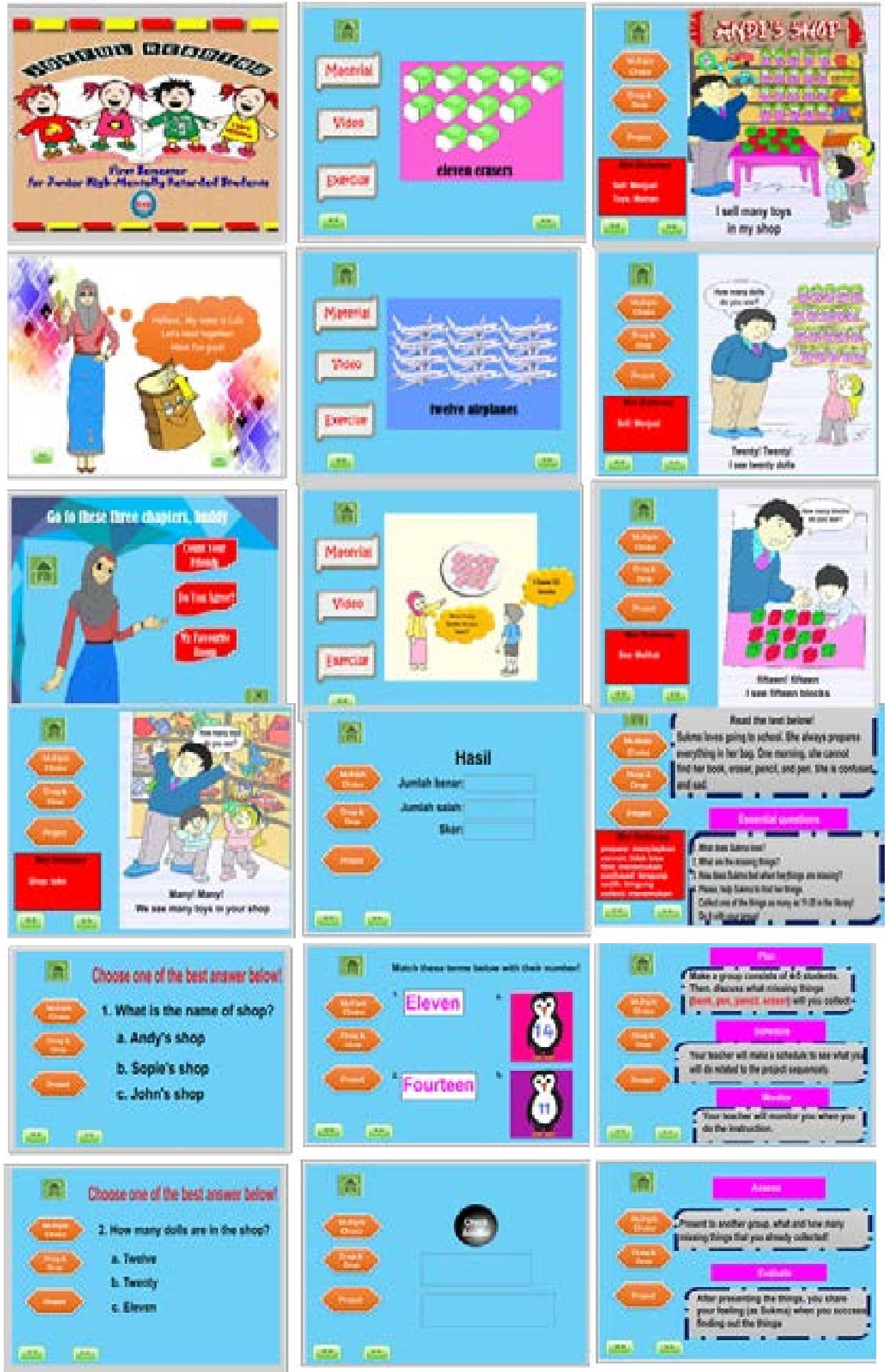